\title{
HAEMATOLOGICAL PROFILE AND SERUM BIOCHEMICAL INDICES OF WEANED RABBITS FED PAWPAW LEAVES (CARICA PAPAYA) AS SUPPLEMENTS TO CORN - SOYBEAN MEAL BASAL DIET
}

\author{
A. J. HENRY, P. O. OZUNG AND P. I. UDOH
}

(Received 22 August 2016; Revision Accepted 20 September 2016)

\begin{abstract}
This study was carried out to determine the haematological profile and serum biochemical indices of rabbits fed pawpaw (Carica papaya) leaves as feed supplement to a corn - soybean mealbasal diet. The study involved thirty six (36) cross bred (New Zealand White X Chinchilla) mixed sex weaned rabbits of five - six weeks old, with average weight of $166.69 \pm 0.02 \mathrm{~g}$. The rabbits were divided into two dietary treatments comprising eighteen (18) rabbits each. The dietary treatments were designated as $T_{1}$ and $T_{2}$ for rabbits fed fresh pawpaw leaves and wilted pawpaw leaves, respectively. The corn - soybean meal basal diet contained $15 \%$ crude protein and $2488.68 \mathrm{Kcal} / \mathrm{Kg}$ metabolizable energy. The feeding trial lasted six weeks, during which period feed and water were provided ad - libitum. The studentized $t$ - test was used compare the results from both dietary treatments. Results obtained from this study revealed that the haematological profile and serum biochemical indices of rabbits recorded no significant $(P>0.05)$ differences between dietary treatments. The study concludes that pawpaw leaves either fresh or wilted when fed as supplements to corn - soybean mealbasal diets will not pose adverse effects on the blood characteristics of rabbits.
\end{abstract}

KEYWORDS: Rabbits, Pawpaw leaves, haematology, serum biochemistry

\section{INTRODUCTION}

Feed scarcity has remained a major limitation to livestock production and productivity (Agbede and Aletor, 2003). The high cost of animal feeds precipitated by the ever increasing cost of feed ingredients has resulted in poor nutrition leading to declining productivity of animals in developing nations like Nigeria (Nodu et al., 2014). According to Fetuga (1997) there is a disappointing rate and low level of performance in the Nigerian livestock industry, due to high cost of feeds, poor quality feeds and inefficiency in production and distribution in the feed industry. The low level of livestock production has affected adequate protein intake. However, intensive rabbit production and domestication can help bridge the meat supply gap in Nigeria and ensure animal protein adequacy.

Rabbits are monogastric herbivores with post gastric digestion that can effectively utilize fodder that is high in fibre such as grasses and legumes (Adegbola et al., 1985). Rabbits have the ability to convert forages and other farm by - products that are not consume directly by humans into highly nutritious meat. They are highly prolific and quite cheap to produce, when compared with other farm animals. Efficient rabbit production is dependent on adequate and proper nutrition (Stanford, 1979). Aduku and Olukosi (1990) reported that rabbits require a crude protein level of $12-$ $17 \%$ and energy level of 2,390 - $2500 \mathrm{Kcal} / \mathrm{Kg} \mathrm{ME}$ for optimum growth in the tropics. Fielding (1991) also reported a crude protein level of $16-18 \%$ as optimum for growing rabbits.

There is the growing trend on the use of non conventional feed ingredients in livestock feed formulation. Standford (1979) reported a wide range of feedstuffs that rabbits can utilized, including non conventional ingredients and kitchen waste materials. One of the promising non - conventional feed materials is pawpaw (Carica papaya) leaves. Pawpaw plant is popular in the tropics and sub - tropics because of its adaptation to diverse soils and climate (Campbell, 1984). The leaves are rich sources of proteolytic enzymes, papain and chymopapain (Poulter and Caygil, 1985). Fresh pawpaw leaves could serve as antiseptic, while the dried leaves are used as tonic and blood purifier (Atta, 1999). Some researchers have documented the utilization of sun cured pawpaw leaf meal in broiler and rabbit diets, respectively (Onyimonyi and Ernest, 2009; Ozung et al., 2012 and Henry et al. 2013). Also, the anti - inflammatory effect of the ethanolic extract of Carica papaya leaves has been used to investigate induced arthritis in rats (Owoleye et al. 2008).

Research findings with pawpaw leaves in animal feeding trials are not totally satisfactory, hence the main thrust of this study. This study was therefore designed to determine the effect of fresh and wilted pawpaw leaves fed as supplements to a corn - soybean meal basal diet on the haematological profile and serum biochemical indices of rabbits in a tropical environment.

A. J. Henry, Department of Animal Science, Faculty of Agriculture, Forestry \& Wildlife Resources Management, University of Calabar, Calabar, Nigeria.

P. O. Ozung, Department of Animal Science, Faculty of Agriculture, Forestry \& Wildlife Resources Management, University of Calabar, Calabar, Nigeria.

P. I. Udoh, Department of Animal Science, Faculty of Agriculture, Forestry \& Wildlife Resources Management, University of Calabar, Calabar, Nigeria. 


\section{MATERIALS AND METHODS}

\section{Location of study:}

The study was carried out at the Rabbitry Unit of the Teaching and Research Farm, Department of Animal Science, University of Calabar, Calabar, Nigeria. Calabar is a tropical environment located at latitude $3^{0} \mathrm{~N}$ and longitude $7^{\circ} \mathrm{E}$ with a land mass of 233.2 square miles $\left(604 \mathrm{Km}^{2}\right)$, average annual rainfall of $1,830 \mathrm{~mm}$ and average temperature of $24^{\circ}-30^{\circ} \mathrm{C}$ as well as relative humidity ranging between 70 and 80\% (Akpan et al., 2006).

\section{Experimental animals and management:}

A total of thirty six (36) cross bred (New Zealand X Chinchilla) weaned rabbits (5 - 6 weeks old with average weight of $166.69 \pm 0.02 \mathrm{~g}$ ) of mixed sexes were used in this study. The animals were housed in wooden cages measuring $65 \times 65 \times 65 \mathrm{~cm}^{3}$ and raised $71 \mathrm{~cm}$ from the ground level. Before the animals were brought into the rabbitry, the cages were thoroughly washed and disinfected with saponated cresol and allowed to dry for seven days. The floor of each cage was covered with wire mesh to allow for the passage of waste materials. Feed and water troughs were provided in each cage, while the feed and water were provided ad - libitum. The rabbits were caged individually in clearly marked cells. The feeding trial lasted six weeks.

Test ingredient (Pawpaw leaves):

Fresh pawpaw leaves were harvested from mature pawpaw plants within the University Staff Quarters. The pawpaw leaves were divided into two categories, namely: Dietary treatment $T_{1}$ comprised of fresh pawpaw leaves that were harvested and fed to the rabbits and $T_{2}$ where the pawpaw leaves were harvested and allowed to wilt (by air - drying at room temperature) for 24 hours before being served to the rabbits.

\section{Experimental diets:}

The pawpaw leaves served as sole supplemented forage (without any other forage) to a corn - soybean meal basal diet that was formulated to meet the nutrient requirements of weaned rabbits. The diets were basically presented as follows: $T_{1}$ (Basal diet + fresh pawpaw leaves) and $T_{2}$ (Basal diet + wilted pawpaw leaves). Each rabbit was served a uniform amount of $100 \mathrm{~g}$ of pawpaw leaves across all the treatments, while the basal diet was offered ad - libitum. The gross composition of the basal diet is presented in Table 1.

Table 1: Gross composition of the basal diet

\begin{tabular}{lc}
\hline Ingredient & \% Composition \\
\hline Yellow maize (Corn) & 38.00 \\
Soybean meal & 26.00 \\
Rice husk & 25.00 \\
Wheat offal & 6.45 \\
Palm oil & 1.00 \\
Bone meal & 3.00 \\
Mineral/vitamin premix & 0.30 \\
Common salt (NaCl) & 0.25 \\
Total & 100.00 \\
Calculated analysis: & \\
\% Crude protein & 15.00 \\
\% Crude fibre & 9.89 \\
ME (Kcal/kg) & $2,488.68$ \\
\hline
\end{tabular}

\section{Blood collection:}

Blood collection was done at end of the $6^{\text {th }}$ week of feeding trial. Blood samples were obtained from the prominent ear vein with the aid of a hypodermic needle and syringe. Two blood samples each were collected per rabbit; one set of the blood samples was collected into plastic bottles containing Ethylene Diamine Tetra acetic acid (EDTA) for haematological profile determinations while the other sample was collected into plain sterile bottles (without EDTA) for the determination of serum biochemical indices. All haematological parameters were determined by conventional laboratory methods of Baker and Silverton (1982); Bitto and Gemade (2001), while serum biochemical indices were determined by methods described by Ochei and Kolhathar (2007).

\section{Statistical analysis:}

All data obtained in this study were subjected to statistical analysis using the studentized $t$ - test for comparing the mean values between blood parameters of rabbits fed fresh pawpaw leaves and wilted pawpaw leaves, respectively.

\section{RESULTS AND DISCUSSION}

Results for haematological profile and serum biochemical indices of weaned rabbits fed fresh and wilted pawpaw leaves as feed supplements to a corn soybean meal basal diet are presented in Tables 2 and 3 , respectively. 
Table 2: Haematological profile of weaned rabbits fed pawpaw leaves as feed supplements

\begin{tabular}{|c|c|c|c|c|c|}
\hline Parameter & $\mathbf{T}_{1}$ & $\mathbf{T}_{2}$ & SEM & LOS & Ref. ranges* \\
\hline Haemoglobin (g/dl) & 8.92 & 10.21 & 0.40 & NS & $10.00-15.00$ \\
\hline Leucocytes (x10\% /L) & 12.99 & 13.18 & 0.22 & NS & $5.00-12.00$ \\
\hline Platelets $\left(\times 10^{9} / \mathrm{L}\right)$ & 113.50 & 120.50 & 0.93 & NS & $250.00-600.00$ \\
\hline Erythrocytes (x10 $12 / L)$ & 3.95 & 4.50 & 0.26 & NS & $4.00-8.00$ \\
\hline $\operatorname{MCV}(\mathrm{fl})$ & 71.03 & 69.07 & 0.49 & NS & $60.00-69.00$ \\
\hline $\mathrm{MCHC}(\%)$ & 33.35 & 33.49 & 0.13 & NS & $30.00-35.00$ \\
\hline $\mathrm{MCH}(\mathrm{pg} /$ cell $)$ & 23.69 & 23.12 & 0.27 & NS & $19.00-22.00$ \\
\hline & \multicolumn{5}{|c|}{$\begin{array}{l}\mathrm{T}_{1}: \text { Fresh pawpaw leaves and } \mathrm{T}_{2} \text { : Wilted pawpaw leaves } \\
\text { SEM: Standard error of means } \\
\text { LOS: Level of significance }(\mathrm{P}>0.05) \\
\text { MCV: Mean corpuscular volume } \\
\text { MCHC: Mean corpuscular haemoglobin concentration } \\
\text { MCH: Mean corpuscular haemoglobin }\end{array}$} \\
\hline
\end{tabular}

Table 3: Serum biochemical indices of weaned rabbits fed pawpaw leaves as feed supplements

\begin{tabular}{llllll}
\hline Parameter & $\mathbf{T}_{1}$ & $\mathbf{T}_{2}$ & SEM & LOS & Ref. ranges $^{*}$ \\
\hline Total protein $(\mathrm{g} / \mathrm{dl})$ & 5.20 & 5.77 & 0.27 & NS & $5.40-7.50$ \\
Urea $(\mathrm{mg} / \mathrm{dl})$ & 10.09 & 11.78 & 0.46 & $\mathrm{NS}$ & $20.00-45.00$ \\
Album in $(\mathrm{g} / \mathrm{dl})$ & 2.79 & 2.58 & 0.16 & $\mathrm{NS}$ & $2.70-5.00$ \\
Globulin $(\mathrm{g} / \mathrm{dl})$ & 2.41 & 3.19 & 0.31 & $\mathrm{NS}$ & $1.50-2.70$ \\
Albumin: globulin & 2.33 & 0.82 & 0.43 & $\mathrm{NS}$ & $0.70-1.89$
\end{tabular}

$\mathrm{T}_{1}$ : Fresh pawpaw leaves and $\mathrm{T}_{2}$ : Wilted pawpaw leaves

SEM: Standard error of means

LOS: Level of significance $(P>0.05)$

${ }^{*}$ Ref. ranges obtained from Medirabbit.com (http://www.medirabbit.com/EN/haematology/bloodchemistry.htm)

\section{Haematological profile of rabbits fed pawpaw leaves as feed supplement:}

Results of haematological parameters were not statistically $(P>0.05)$ affected by dietary treatments (Table 2). The results for haemoglobin concentration in this study were $8.92 \mathrm{~g} / \mathrm{dl}$ for the fresh pawpaw leaves treatment and $10.21 \mathrm{~g} / \mathrm{dl}$ for the wilted pawpaw leaves, respectively. The haemoglobin value for the wilted pawpaw leaves was within the normal ranges $10-15$ $\mathrm{g} / \mathrm{dl}$ and $10-17.5 \mathrm{~g} / \mathrm{dl}$ reported by Aduku and Olukosi (1990); Flecknell (2000) and Medirabbit (2011) for rabbits. However, the value for the fresh pawpaw leaves was lower than the normal range $10-15 \mathrm{~g} / \mathrm{dl}$ for rabbits. The variation in haemoglobin contents could be attributed to the form of pawpaw leaves served to the rabbits. The anti - nutrients in the fresh pawpaw leaves might have adversely affected the haemoglobin content even though the rabbits showed no obvious signs of toxicity; while the normal haemoglobin content in the wilted leaves indicated that such leaves were quite safe for the normal physiological function of haemoglobin such as transport of oxygen and carbon (iv) oxide to and from tissues of the body of the rabbits (Njidda et al., 2006). The leucocyte counts obtained in this study $\left(12.99\right.$ and $\left.13.18 \times 10^{9} / \mathrm{L}\right)$ for fresh and wilted pawpaw leaves, respectively were slightly higher than the normal range of leucocytes $\left(5.00-12.00 \times 10^{9} / \mathrm{L}\right)$ for rabbits reported by Medirabbit (2011). The values were also higher than the range $3.10-3.97 \times 10^{9} / \mathrm{L}$ reported by Bitto et al. (2006) for rabbits fed pawpaw peel meal based - diets. The differences in leucocyte contents may be attributable to inherent medicinal properties of pawpaw leaves used in this study, especially as there was no record of mortality. This explains an effective anti-body production and better disease resistance and immunity by the rabbits (Nwosu, 1979; Mbanasor et al. 2003). According to Ihedioha (2008) leucocyte counts are of immense clinical importance as lymphocytes are responsible for immune - mediated defense of the body. The platelet counts recorded in this study were 113.50 and $120.50 \times 10^{9} / \mathrm{L}$ for rabbits fed fresh and wilted pawpaw leaves respectively. The values were however lower than the normal range $\left(250.00-600.00 \times 10^{9} / \mathrm{L}\right)$ for rabbits reported by Medirabbit (2011). The erythrocyte counts were 3.95 and $4.50 \times 10^{12} / \mathrm{L}$ respectively for fresh and wilted pawpaw leaves, which were within the range $4.00-8.00 \times 10^{12} / \mathrm{L}$ reported by Medirabbit (2011), but lower than the range $4.42-5.13$ $\mathrm{x} 10^{12} / \mathrm{L}$ reported by Etim and Oguike (2011) for female rabbits fed Aspilia africana leaf meal. The differences in values could be attributed to different test materials and ages of rabbits in the separate studies. Furthermore, the mean corpuscular volume was between 71.03 and 69.07 $\mathrm{fl}$ for rabbits fed fresh and wilted pawpaw leaves, 
respectively. The values were in agreement with the MCV content $(60.00-69.00 \mathrm{fl})$ reported for apparently healthy rabbits (Medirabbit, 2011); but higher than 32.75 - $34.00 \mathrm{fl}$ reported by Bitto et al. (2006). Likewise the mean corpuscular haemoglobin obtained in this study was $23.69 \mathrm{pg} / \mathrm{cell}$ for rabbits fed fresh pawpaw leaves and $23.12 \mathrm{pg} / \mathrm{cell}$ for rabbits fed wilted pawpaw leaves, respectively.

\section{Serum biochemical indices of weaned rabbits fed pawpaw leaves as feed supplement:}

Results of serum biochemical indices of rabbits fed pawpaw leaves were not statistically $(P>0.05)$ affected by dietary treatments (Table 3 ). The serum total protein content was $5.20 \mathrm{~g} / \mathrm{dl}$ for rabbits fed fresh pawpaw leaves and $5.77 \mathrm{~g} / \mathrm{dl}$ fed wilted pawpaw leaves. The total protein contents were within the normal reference range $(5.4-7.5 \mathrm{~g} / \mathrm{dl})$ reported by Medirabbit (2011). This suggests that normal protein metabolism occurred in rabbits, since protein synthesis is related to the amount of protein available in the diet (lyayi and Tewe, 1998). The urea contentwas $10.09 \mathrm{mg} / \mathrm{dl}$ in the rabbits fed raw pawpaw leaves and $11.78 \mathrm{mg} / \mathrm{dl}$ in rabbits fed the wilted pawpaw leaves, respectively. These values were lower than the range $20-45 \mathrm{mg} / \mathrm{dl}$ reported by Medirabbit (2011). The differences in urea content could be attributed to variation in ages of rabbits in the different ecological zones. High urea level is an indication of low protein quality (Esonu et al., 2001). The low urea levels in this study revealed that the corn - soybean meal basal diet and pawpaw leaves were rich in protein with a corresponding positive effect in the proper functioning of the kidneys. The albumin values $(2.79$ and $2.58 \mathrm{~g} / \mathrm{dl}$ for rabbits fed fresh and pawpaw leaves, respectively) were comparable with the normal clinical range $(2.70-5.00$ $\mathrm{g} / \mathrm{dl})$ for apparently healthy rabbits reported by Medirabbit (2011). This suggests a proper functioning of the liver of rabbits fed pawpaw leaves. Furthermore, the globulin concentration was 2.41 and $3.19 \mathrm{~g} / \mathrm{dl}$ respectively for rabbits fed fresh and wilted pawpaw leaves. These values were within the range $2.50-4.50$ g/dl given by Burke (1994) for rabbits. All the serum biochemical indices in this study recorded no significant differences between dietary treatments, implying that pawpaw leaves (either fresh or wilted) will not impact negatively on the serum biochemistry of rabbits.

\section{CONCLUSION}

Results obtained in this study have shown that pawpaw leaves can be utilized by weaned rabbits as feed supplement in corn - soybean meal basal diets without adverse effects on their haematological profile and serum biochemical indices.

\section{RECOMMENDATION}

It is therefore recommended that farmers can supplement basal diets with either fresh or wilted pawpaw leaves for rabbits. These leaves have been identified as forage for rabbits that could be used alongside other well-known forages like Tridax procumbens and Gliricidia sepium for rabbits in the tropics.

\section{REFERENCES}

Adegbola, T. A., Tibi, E. U and Asogwa, D. C., 1985. Feed intake and digestibility of rabbitson all forage, forage plus concentrates and all concentrate diets. Journal of Animal Production Research, 5: $185-191$.

Aduku, A. O and Olukosi, J. O., 1990. Rabbit management in the tropics, production, processing, utilization, marketing, economics, practical training, research and future prospects, Abuja, Living Book Series, GU Publications, $150 \mathrm{Pp}$.

Agbede, J. O and Aletor, V. A., 2003. Comparative evaluation of weaning food from glycerides and leucaena leaf protein concentrates and some commercial brands in Nigeria. Journal of Science of Food and Agriculture, 84: $21-34$.

Akpan, E. R., Offem, J. O and Nya, A. E., 2006. Baseline ecological studies of the great Qua River, Nigeria, 'Physico - chemical studies' Ecoserve, retrieved $21^{\text {st }}$ July, 2016, 1:23pm.

Atta, K. B., 1999. The power of garlic. Cardiovascular Disease Prevention Association Bulletin, Buea, Cameroon, P. 72.

Baker, F S and Silverton, R. E., 1982. Introduction to Medical Laboratory Technology, $5^{\text {th }}$ edition, Butterworth S. C., London, Pp. $481-494$.

Bitto, I. I and Gemade, M., 2001. Preliminary investigations on the effect of pawpaw peel meal on growth, visceral organ and endocrine gland weights, testicular morphometry and haematology of male rabbits. Global Journal of Pure and Applied Sciences, 7 (4): $62-65$.

Bitto, I. I., Arubi, J. A and Gumel, A. A., 2006. Reproductive tract morphometry and some haematological characteristics of female rabbits fed pawpaw peel meal based - diets. African Journal of Biomedical Research, 9 (3): 199 204.

Burke, J., 1994. Clinical care and medicine of pet rabbits. Proceedings of the Michigan Veterinary Conference, Pp. $49-77$.

Campbell, C. W., 1984. Papaya - tropical fruits and nuts. Handbook on Tropical Crops. Boca, CRC Press Inc., Raton, Florida, Pp. 246 - 247.

Esonu, B. O., Emenalom, O. O., Udedibie, A. B. I., Berbert, U., Ekpor, C. F., Okoli. C. E and Iheukwumere, F. C., 2001. Performance and chemistry of weaner pigs fed rawmucuna bean (Velvet bean) meal. Tropical Animal Production Investigation, 4: 49 54.

Etim, N. N and Oguike, M. A., 2011. Haematological and serum biochemistry of rabbits fed Aspilia Africana leaf meal based - diets. Nigerian 
Journal of Agriculture, Food and Environment, 7 (4): $121-127$.

Fetuga, B. L., 1997. Animal production in Nigeria and feed supplies. Nigerian Journal of Animal Production, 4 (1): $19-41$.

Fielding, D., 1991. Rabbits: The Tropical Agriculturist $\left(15^{\text {th }}\right.$ edition), London, CTA, Macmillan Publishers, Pp. $16-17$.

Flecknell, P., 2000. Manual of Rabbit Medicine and Surgery, Gloucester, British Small Animal Veterinary Association.

Henry, A. J., Williams, G. A and Effiong, O. O., 2013. Linear body measurements and carcass characteristics of rabbits fed orange (Citrus sinesis) waste meal as alternative fibre source in diet. Advances in Natural Science, 6(1): 20 24.

Ihedioha, J. I., Okorie - Kanu, C. O and Iwuogu, U. M.,

2008. Leucocyte alterations associated with continual sub - acute blood loss. Proceedings of $33^{\text {rd }}$ Annual Conference of Nigerian Society of Animal Production held in Ogun State, Nigeria.

lyayi, E. A and Tewe, O. O., 1998. Serum total protein, urea, creatinine levels as indices in cassava diets for pigs. Tropical Veterinary, 8: 11-15.

Mbanasor, U. U., Anene, B. M., Chinezie, A. B., Nnaji, T. O., Eze, J. I and Ezekwe, A. G., 2003. Haematology of normal trypanosome - infected muturu Cattle in South - eastern Nigeria. Nigerian Journal of Animal Production, 30: $236-241$.

Medirabbit., 2011. Complete blood count and biochemical reference values in rabbits. Retrieved from www.medirabbit.com, $22^{\text {nd }}$ July, 2016, $12: 30 \mathrm{pm}$.

Njidda, A. A., Igwebuike, J. U and Isidahome, C. E., 2006. Haematological parameters and carcass characteristics of weaned rabbits fed graded levels of molasses. Global Journal of Agricultural Science, 5 (7): $167-172$.

Nodu, M. B., Okpeku, M. and Abezi, A. E., 2014. Haematological characteristics of rabbits fed a mixture of Alchornea cordifolia/ Pawpaw leaf meal. Journal of Agricultural and Veterinary Sciences, 7 (1): $92-96$.

Nwosu, C. C., 1979. Characteristics of local chicken of Nigeria and its potentials for egg and meat production. In: Poultry Production in Nigeria. Proceedings of $1^{\text {st }}$ National Seminar on Poultry Production, Zaria.

Ochei, J and Kolhatkar, A., 2007. Medical Laboratory Science Theory and Practice, $6^{\text {th }}$ edition, McGraw - Hill Publishing Company Limited, New York, USA, 1338pp.

Onyimonyi, A. E and Ernest, O., 2009. An assessment of pawpaw leaf meal as protein ingredient for finishing broilers. International Journal of Poultry Science, 8 (10): 995 - 998.

Owoleye, B. V., Olubori, A. M., Adeoye, A. F and

Ayodele, O. S., 2008. Anti - inflammatory activities of ethanolic extract of Carica papaya leaves. Inflammopharmacology, 16 (4): $168-173$.

Ozung, P. O., Ubua, J. A., Anya, M. I., Nsa, E. E., Ebegbulem, V. N and Etim, S. E., 2012. Evaluation of Growth Performance and some Haematological Characteristics of weaned rabbits fed pawpaw peel meal based diets in Cross River Rainforest Zone. International Journal of Science and Nature (IJSN), Vol. 3 (4): $784-787$.

Poulter, N. H and Caygil, J. C., 1985. Production and utilization of papain, a proteolytic enzyme from Carica papaya L., Tropical Science, 25: 123 127.

Stanford, J. I., 1979. The Domestic Rabbit, $3^{\text {rd }}$ edition, Granada Publishing Company Limited, London. 